\title{
Diet of the gelatinous zooplankton in Hardangerfjord (Norway) and potential predatory impact by Aglantha digitale (Trachymedusae)
}

\author{
F. Pagès ${ }^{1, *}$, H. E. González ${ }^{2}$, S. R. González ${ }^{3}$ \\ 'Alired-Wegener-Institut für Polar- und Meeresforschung, Columbusstraße, D-27569 Bremerhaven, Germany \\ ${ }^{2}$ Instituto de Biología Marina, Casilla 567, Universidad Austral de Chile, Valdivia, Chile \\ ${ }^{3}$ Netherlands Institute for Sea Research, PO Box 59, 1790 AB Den Burg, The Netherlands
}

\begin{abstract}
The abundance, spatial distribution and diet of the gelatinous zooplankton collected at 5 stations along the Hardangerfjord (Norway) in spring 1992 were investigated. Medusae and siphonophores dominated in abundance and were concentrated in the upper $50 \mathrm{~m}$ where a strong halocline (28.2 to $34.5 \mathrm{psu}$ ) was present. Obelia spp. (up to 158.1 ind. $\mathrm{m}^{-3}$ ), Aglantha digitale (up to 57.4 ind. $\mathrm{m}^{-3}$ ), Rathkea octopunctata (up to 14.7 ind. $\mathrm{m}^{-3}$ ) and Lensia conordea (up to 38.7 eudoxids $\mathrm{m}^{-3}$ ) were the most abundant species. Their stomach contents showed a wide variety of food items but the copepods Oithona similis and Temora longicornis and the cladoceran Evadne nordmanni were the main prey. The daily predation rate on copepods estimated for $A$. digitale was 23.5 to 145.6 copepods $\mathrm{m}^{-3} \mathrm{~d}^{-1}$ The percentage of the copepod population consumed daily by $A$. digitale was 0.2 to $1.5 \%$. Excluding nauplii, since this stage was never found in the stomach of the specimens examined, the percentage consumed increases to $1.6-6.6 \%$. A digitale potentially ingested up to 5.7 and $8.7 \%$ of the 0 . similis and $T$. longicornis (adults and copepodites) populations respectively. These low estimations of the predatory impact might not reduce standing stocks of the copepod populations. However, the rates of predation might have been underestimated and the total predatory impact by all cnidarian species could have been substantial.
\end{abstract}

KEY WORDS: Fjord Gelatinous zooplankton Aglantha digitale Predation Norway

\section{INTRODUCTION}

The particular conditions that fjords offer, as semienclosed ecosystems, have promoted investigations concerned with the pelagic food web. In Norway, such investigations have intensified during the past decade in order to gain information on the exploitation of natural fish stocks. The zooplankton communities in Norwegian fjords, through which most of the energy flow from the primary producers to the fish passes, normally are dominated by copepods and euphausinds, in terms of both abundance and biomass (Giske et al. 1990, Baliño \& Asknes 1993). Occasionally, however, conspicuous blooms of gelatinous zooplankton occur (Fosså

- Correspondence address: Institut de Ciències del Mar (CSIC), Plaça del Mar s/n, E-08039 Barcelona, Spain

E-mail: fpages@icm.csic.es
1992) which may have important trophic implications for the plankton communities. The potential impact of medusae, siphonophores and ctenophores on the trophodynamics of the Norwegian fjords already has been noted (Matthews \& Bakke 1977, Fosshagen 1980) but has yet to be quantified, although Båmstedt et al. (1994) recently have published results based on experimental work under laboratory conditions. A review of the zooplankton investigations carried out in fjords of the northern hemisphere shows that the medusae Aglantha digitale and Rathkea octopunctata are the most frequently occurring cnidarians and often the most abundant (Zelickmann et al. 1969, Barry 1974, Magnesen 1988). In the Bedford Basin (Canada), where both species dominated the gelatinous community in spring 1988, Matsakis \& Conover (1991) estimated that gelatinous zooplankton consumed on average $15.8 \%$ of the prey resource over $4 \mathrm{~m}$, ranging from 
$2 \%$ in March to $59 \%$ in early May, at which time these animals controlled the zooplankton dynamics. They observed that $R$. octopunctata was the dominant hydromedusan from mid-March to the end of June and accounted for $80 \%$ ( 65 ind. $\mathrm{m}^{-3}$ ) of the carbon biomass of jellyfish in May. Likewise $A$. digitale is one of the most common cnidarians in the North Atlantic and North Pacific oceans where it is widely distributed from about $35^{\circ} \mathrm{N}$ into the Arctic Ocean (Kramp 1959). It shows high abundances in the North Atlantic (up to 40 ind. $\mathrm{m}^{-3}$; Williams \& Conway 1981) but little is known about its diet and predatory impact.

The great abundance of gelatinous zooplankton collected in the Hardangerfjord during the International Coccolithophorid Expedition allowed us to investigate the role of this community in this semi-enclosed ecosystem. The composition, abundance and distribution of the entire zooplankton community were investigated and, additionally, the stomach contents of the most abundant species were examined in order to gain knowledge on these species' diet and potential predatory impact.

Hardangerfjord is located south of Bergen on the west coast of Norway (Fig. 1). Its dimensions $(180 \mathrm{~km}$ long and $900 \mathrm{~m}$ deep) make it one of the largest and deepest fjords in the world. A synoptic research program during the 1950 s and 1960s (Braarud 1961) studied several aspects of the ecology of this fjord. The hydrographical data for a single year (1955-56) was published by Sælen (1962), and Lie (1967) investigated the numerical abundance and composition of the zooplankton community during the same period. However, no further data on the hydrography and zooplankton have been published.

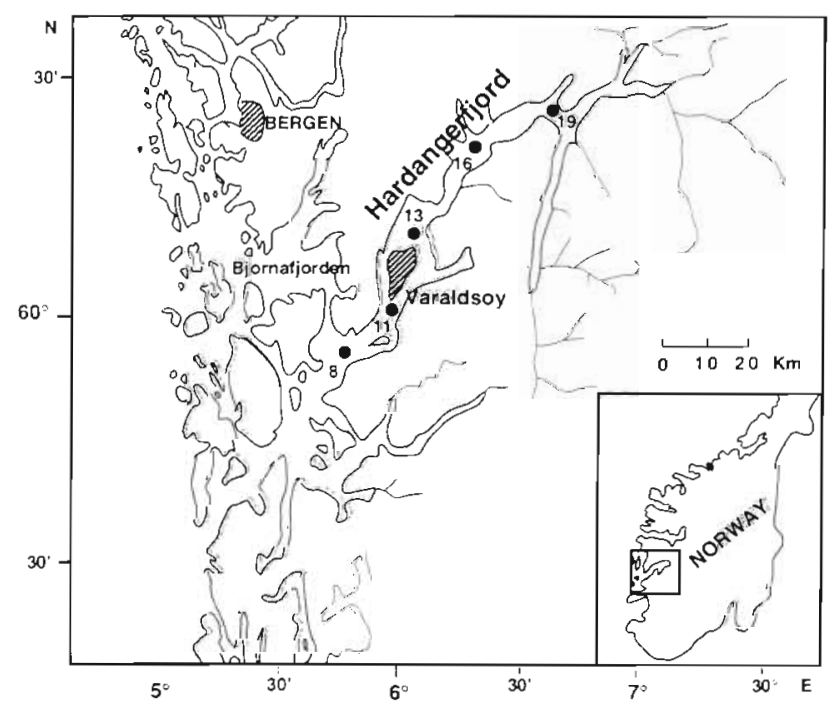

Fig. 1. The study area on the west cost of Norway, showing the position of the 5 stations along the Hardangerfjord

\section{MATERIAL AND METHODS}

Zooplankton was collected at 5 stations along the Hardangerfjord (Fig. 1) by the RV 'Pelagia' during the International Coccolithophorid Expedition (27 April to 4 May 1992). Samples were collected once (morning) or twice (morning and late afternoon) a day always during daylight. Two sets of vertical samples (haul rate $1 \mathrm{~m} \mathrm{~s}^{-1}$ ) were collected consecutively from the $0-50$, 50-100 and 100-300 m depth strata using (1) an opening/closing WP-2 net with a $200 \mu \mathrm{m}$ mesh, and (2) a modified WP-2 net (mesh size $50 \mu \mathrm{m}$ ). The latter allowed the smaller size fraction of the copepod community (e.g. Oithona, Oncaea, Microcalanus) to be sampled. Samples were preserved in $4 \%$ buffered formaldehyde in sea water immediately after the net arrived on board. At each station temperature and salinity data were obtained by means of a calibrated CTD probe. CTD casts were carried out in conjunction with the zooplankton sampling. As the samples from the deepest depth range proved to contain very few specimens, only the samples collected in the 0-50 and 50-100 m strata were examined. Each sample was divided in 2 using a Folsom splitter, one portion being used exclusively for the study of the gelatinous zooplankton and the other for the identification of the remainder of the zooplankton.

All the gelatinous (mainly medusae and siphonophores) and non-gelatinous species were identified and enumerated, and the counts standardized to number of specimens per $\mathrm{m}^{3}$. The volume of water filtered was calculated using a flow-meter. In addition the medusae and siphonophores were examined under a dissecting microscope to identify and quantify the prey items in their guts. The manubrium (medusae) or gastrozooid (siphonophores) of each specimen was cut longitudinally to display its contents.

Electivity indices (C) for the common zooplankton taxa were calculated from the numbers of prey $\mathrm{m}^{-3}$ and the number of prey of the main cnidarian species for each sample, and the significance tested (chi-square) according to Pearre (1982). Statistical analysis of data was carried out using a non-parametric test, the Spearman rank correlation (r) (Zar 1984).

\section{RESULTS}

\section{Hydrography}

A steep halocline was located in the top $75 \mathrm{~m}$ of the water column along the fjord, with the salinity increasing from 28.2 psu at the surface to 34.5 psu (Fig 2A). Below $200 \mathrm{~m}$ the salinity was stable at ca $35.0 \mathrm{psu}$. The temperature in the upper $50 \mathrm{~m}$ was stable $\left(7.5^{\circ} \mathrm{C}\right)$ 
Fig. 2. (A) Salinity (psu) and (B) temperature $\left({ }^{\circ} \mathrm{C}\right)$ profiles along the Hardangerfjord over the sampling period

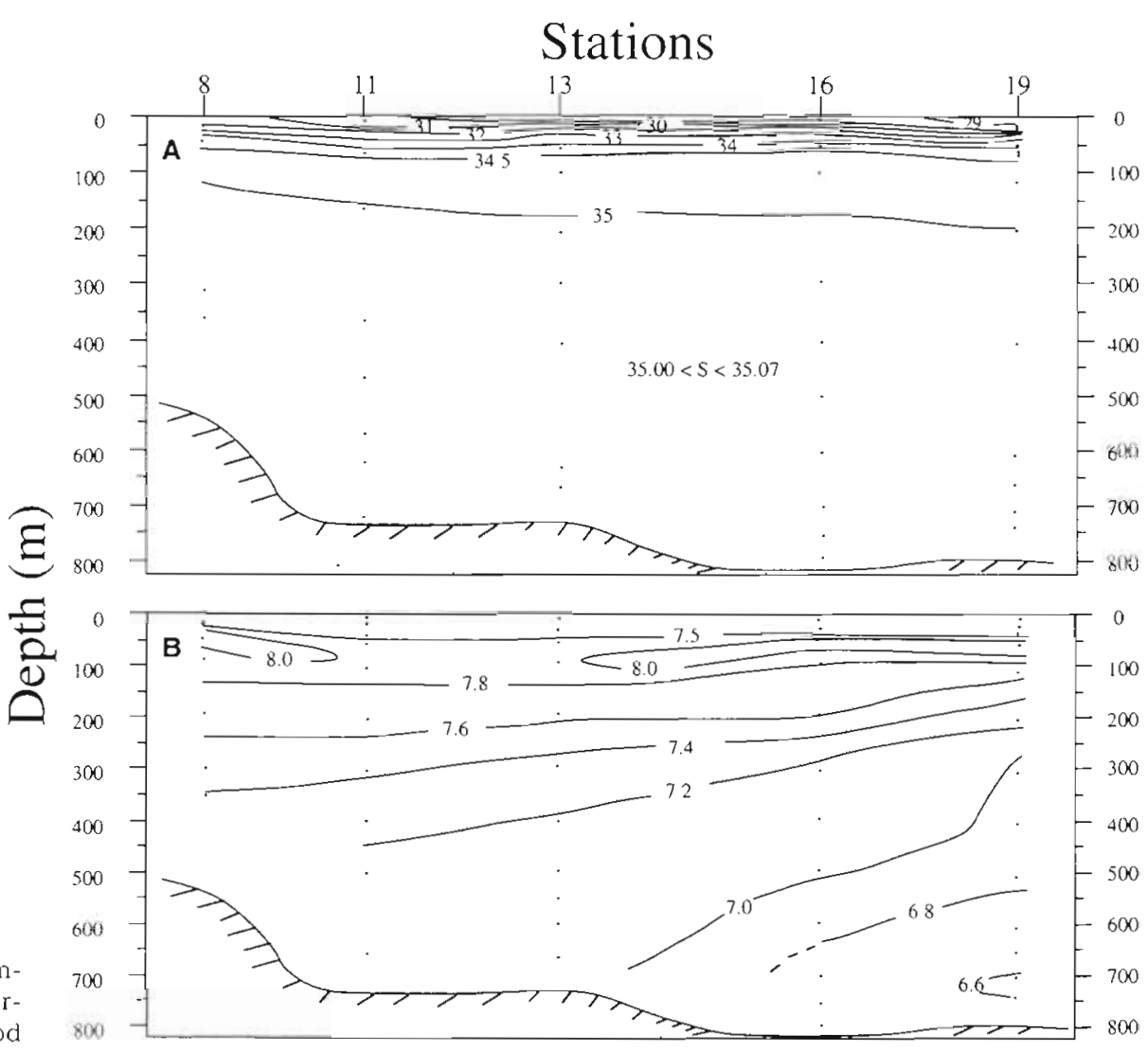

throughout the $135 \mathrm{~km}$ length of the transect (Fig. 2B). It increased slightly, up to $8.0^{\circ} \mathrm{C}$, in the $50-100 \mathrm{~m}$ depth range, and below $150 \mathrm{~m}$ it decreased progressively toward the inner fjord, reaching $6.6^{\circ} \mathrm{C}$ at $700 \mathrm{~m}$ at the innermost station.

\section{Species composition and abundance}

During the short sampling period, the gelatinous zooplankton was dominated by cnidarians and only an occasional ctenophore and no salps were found in the samples. Six medusae and 4 siphonophore species were collected at the 5 stations (Table 1), all of which had been recorded previously in Norwegian waters. The most abundant medusae were Obelia spp., Aglantha digitale and Rathkea octopunctata while Lensia conoidea was the predominant siphonophore. However, the 4 species did not show the same distribution patterns along the fjord.

Obelia spp. (up to $3 \mathrm{~mm}$ in diameter) were by far the most abundant species, with densities along the fjord in the top $50 \mathrm{~m}$ normally in the range 32.0 to 48.2 ind. $\mathrm{m}^{-3}$, but peaking at 158.1 ind. $\mathrm{m}^{-3}$ at Stn 11. Both Aglantha digitale $(0.5$ to $10 \mathrm{~mm}$ high) and Rathkea octopunctata (0.5 to $2 \mathrm{~mm}$ high) were also most abundant in the top $50 \mathrm{~m}$ at the 2 outermost stations, with reduced numbers in the mid-fjord region, but increasing toward its head (Table 1). In contrast, the siphonophore Lensia conoidea was most abundant in the upper $50 \mathrm{~m}$ at the 2 innermost stations. Eudoxids (6 $\mathrm{mm}$ high) of this species predominated over the polygastric stage (up to $28 \mathrm{~mm}$ high) in all the samples, and most of their gonophores were mature, indicating that the population was reproductively active.

On average, $87 \%$ of the total non-cnidarian mesozooplankton was concentrated in the top 0-50 m of the water column with, respectively, 12 and $1 \%$ being found in the 50-100 and 100-300 m depth strata. In the top $50 \mathrm{~m}$ the cladoceran Evadne normanni and the copepods Oithona similis and Temora longicornis were among the most abundant species (Table 2). E. nordmanni increased in abundance toward the head of the fjord (Stn 19), while T. longicornis, Calanus finmarchicus, and the appendicularians Fritillaria borealis and Oikopleura sp. peaked at Stn 11 and steadily decreased toward the head. The distribution of the nauplii and copepodites of $O$. similis did not show a distinct gradient along the fjord, but they were markedly more abundant at the innermost station. The remainder of the copepods and meroplanktonic larvae showed a high variability in abundance along the fjord without any distinct gradients. 
Table 1. Abundances (ind $\mathrm{m}^{-3}$ ) of medusae and siphonophores at each station in Hardangerfjord, Norway. Data for each species showed in depth order $(0-50,50-100 \mathrm{~m})$. Systematics according to Bouillon et al. (1992)

\begin{tabular}{|c|c|c|c|c|c|c|}
\hline \multirow[t]{2}{*}{ Species } & & \multicolumn{5}{|c|}{ Station } \\
\hline & & 8 & 11 & 13 & 16 & 19 \\
\hline \multicolumn{7}{|l|}{ Class Hydrozoa } \\
\hline Corymorpha nutans & & 0 & 0.1 & 0 & 0 & 0 \\
\hline M. Sars, 1835 & & 0 & 0 & 0 & 0 & 0 \\
\hline Rathkea octopunctata & & 14.2 & 14.7 & 7.6 & 4.2 & 10.5 \\
\hline (M. Sars, 1835) & & 1 & 2.3 & 0 & 0.1 & 1.7 \\
\hline \multirow{2}{*}{\multicolumn{2}{|c|}{ Obelia spp. }} & 48.2 & 158.1 & 32 & 35.9 & 40.3 \\
\hline & & 1 & 25.4 & 0.5 & 9.2 & 3.2 \\
\hline \multirow{2}{*}{\multicolumn{2}{|c|}{$\begin{array}{l}\text { Mitrocomella polydiademata } \\
\text { (Romanes, } 1876 \text { ) }\end{array}$}} & 0.4 & 0 & 0 & 0 & 0.2 \\
\hline & & 0 & 0 & 0 & 0 & 0 \\
\hline \multirow{2}{*}{\multicolumn{2}{|c|}{$\begin{array}{l}\text { Eutonina indicans } \\
\text { (Romanes, 1876) }\end{array}$}} & 0 & 0.1 & 0.1 & 0 & 0 \\
\hline & & 0 & 0 & 0 & 0 & 0 \\
\hline \multirow{2}{*}{\multicolumn{2}{|c|}{$\begin{array}{l}\text { Aglantha digitale } \\
\text { (O. F. Muiler, 1776) }\end{array}$}} & 39.2 & 57.4 & 17.5 & 8.8 & 21.5 \\
\hline & & 2.2 & 5.5 & 0.2 & 0.7 & 1.1 \\
\hline \multicolumn{7}{|l|}{ Order Siphonophorae } \\
\hline \multicolumn{2}{|l|}{ Cordagalma cordiformis } & 0 & 0 & 0 & 0.3 & 0 \\
\hline \multicolumn{2}{|l|}{ Totton, 1932} & 0 & 0.1 & 0 & 0 & 0 \\
\hline \multicolumn{2}{|l|}{ Nanomia cara } & 0 & 0.2 & 0.2 & 0.2 & 0.2 \\
\hline A. Agassiz, 1865 & & 0 & 0.1 & 0.1 & 0 & 0 \\
\hline \multirow{4}{*}{$\begin{array}{l}\text { Lensia conoidea } \\
\text { (Kefferstein \& Ehlers 1860) }\end{array}$} & Polygastric stage & 0.7 & 0.6 & 0.3 & 1.1 & 0.9 \\
\hline & & 0.5 & 0 & 0.2 & 0.1 & 0.4 \\
\hline & Eudoxids & 20.5 & 9.5 & 7.6 & 11.7 & 38.7 \\
\hline & & 3.2 & 6 & 1.8 & 0.9 & 4.7 \\
\hline \multirow{4}{*}{$\begin{array}{l}\text { Dimophyes arctica } \\
\text { (Chun 1897) }\end{array}$} & Polygastric stage & 0 & 0 & 0 & 0 & 0 \\
\hline & & 0.3 & 0.2 & 0 & 0 & 0 \\
\hline & Eudoxids & 0 & 0 & 0 & 0 & 0 \\
\hline & & 0.2 & 0 & 0 & 0 & 0 \\
\hline \multicolumn{2}{|l|}{ Total } & 65.8 & 140.2 & 34.0 & 36.6 & 61.7 \\
\hline
\end{tabular}

Table 2. Abundance (ind. $\mathrm{m}^{-3}$ ) of the non-gelatinous mesozooplankton in the upper $50 \mathrm{~m}$ of the Hardangerfjord

\begin{tabular}{|c|c|c|c|c|c|c|}
\hline \multirow{2}{*}{ Taxon } & & \multicolumn{5}{|c|}{ Station } \\
\hline & & 8 & 11 & 13 & 16 & 19 \\
\hline \multirow[t]{3}{*}{ Oithona similis } & Nauplii & 5320 & 4048 & 3724 & 6882 & 19442 \\
\hline & Copepodites & 1209 & 1179 & 1036 & 955 & 4136 \\
\hline & Adults & 203 & 341 & 383 & 195 & 1297 \\
\hline Evadne normanni & & 291 & 832 & 648 & 1070 & 4555 \\
\hline Temora longicornis & Adults and copepodites & 106 & 291 & 200 & 46 & 595 \\
\hline & Nauplii & 2297 & 3222 & 2868 & 2865 & 5791 \\
\hline Calanus finmarchicus & & 39 & 349 & 88 & 53 & 12 \\
\hline Fritillaria borealis & & 88 & 163 & 14 & 70 & 21 \\
\hline Oikopleura sp. & & 47 & 148 & 29 & 7 & 0 \\
\hline Lamellibranchia larvae & & 17 & 133 & 14 & 7 & 6 \\
\hline Echinoderm larvae & & 97 & 29 & 117 & 78 & 300 \\
\hline Bryozoa larvae & & 53 & 74 & 0 & 7 & 139 \\
\hline Polychaeta larvae & & 17 & 29 & 29 & 0 & 10 \\
\hline Microcalanus sp. & & 8 & 0 & 0 & 0 & 42 \\
\hline Paracalanus parvus & & 0 & 0 & 29 & 15 & 11 \\
\hline Pseudocalanus elongatus & & 35 & 59 & 0 & 5 & 42 \\
\hline Podon sp. & & 8 & 44 & 0 & 0 & 249 \\
\hline Total & & 9835 & 10941 & 9179 & 12255 & 36648 \\
\hline
\end{tabular}




\section{Cnidarian diets}

Although Obelia spp. were the most abundant cnidarians, and consequently could have a major predatory impact on the zooplankton community, no identifiable prey was found in their stomachs. The fact that the stomachs are minute $(0.2$ to $0.4 \mathrm{~mm}$ wide) indicates that microplankton may be the main food resource. Microzooplankton prey, mostly tintinnids, comprised $100 \%$ of the prey items found in 1 to $2 \mathrm{~mm}$ specimens of Obelia sp. in British Columbian (Canada) waters (Purcell \& Mills 1988, Purcell \& Grover 1990). In our samples, a large number of specimens had open mouths and any contents may have been lost.

Nonetheless, the stomach contents of Aglantha digitale, Rathkea octopunctata and the eudoxids of Lensia conoidea could be analyzed. A. digitale had the highest percentage of specimens with stomach contents (Table 3), with 377 (50.8\%) having filled guts of 742 specimens examined from the upper $100 \mathrm{~m}$. However, these numbers are derived mainly from specimens collected in the 50-0 m depth range, where 349 (50.2\%) of the 694 specimens analyzed had gut contents. At each station, with the exception of the outermost one $(33 \%)$, the percentage of filled guts was slightly above $50 \%$ This trachymedusan consumed a wide variety of food items, with the copepod Oithona similis being the main prey (Table 3). Among the copepods ingested, only adults and copepodite stages were found. Tintinnids and dinoflagellates occurred in a substantial number of stomachs, but were not counted because their numbers would have been underestimated, as tintinnids in particular occurred in the guts forming part of amorphous aggregates. The remainder of the food items identified consisted of eggs, bivalve larvae, detritus, appendicularians and their faecal pellets, and a relatively large number of unidentified chitinous exoskeletons. At Stn $11(50-0 \mathrm{~m}), 31.1 \%$ of stomachs were full of lipids. Despite the high occurrence of tintinnids, dinoflagellates, lipid drops, detritus and crustacean exoskeletons in the gut contents, selection of these prey items was not estimated due to the lack of in situ densities. A digitale showed positive selection for Oikopleura spp. at the 4 stations where these appendicularians occurred (Table 4), positive selection for Evadne nordmanni at Stn 8, and positive and negative selection for $O$. similis at the inner-and outermost stations respectively.

The guts of 340 Rathkea octopunctata were examined, but only $52(15.2 \%)$ had contents. The cladoceran Evadne nordmanni was the most abundant prey item $(87.9 \%)$ and was positively selected for at all stations. Oithona similis was the only copepod found among the prey $(9.6 \%)$ but was selected against at 4 stations (Table 4). 
Table 4. Indices of prey selection $\left(C_{i}\right.$ Pearre 1982) calculated from the 6 most identifiable prey in the gut contents of the main cnidarian species and therr in situ densities at the 5 stations sampled. $\cdots p<0.005, " p<0.05$ : significantly different from no selection

\begin{tabular}{|c|c|c|c|c|c|c|}
\hline \multirow{2}{*}{ Species } & \multicolumn{6}{|c|}{ Food items } \\
\hline & $\begin{array}{l}\text { Oithona } \\
\text { similis }\end{array}$ & $\begin{array}{c}\text { Temora } \\
\text { longicornis }\end{array}$ & $\begin{array}{l}\text { Other } \\
\text { copepods }\end{array}$ & $\begin{array}{c}\text { Evadne } \\
\text { nordmanii }\end{array}$ & $\begin{array}{l}\text { Oikopleura } \\
\text { spp. }\end{array}$ & $\begin{array}{c}\text { Invertebrate } \\
\text { larvae }\end{array}$ \\
\hline Aglantha digitale & 0.01 & 0.01 & $0.02 \cdots$ & $0.03 \cdots$ & $0.05 \cdots$ & 0 \\
\hline Rathkea octopunctata & $-0.04 \cdots$ & -0.01 & -0.01 & $0.06 \cdots$ & 0 & -0.01 \\
\hline Lensia conoidea & $-0.03 \cdots$ & $0.02 \cdots$ & $0.03 \cdots$ & $0.03 \cdots$ & -0.01 & $-0.01^{*}$ \\
\hline
\end{tabular}

Of the 635 gastrozooids of Lensia conoidea eudoxids dissected, only $99(15.6 \%)$ contained the remains of prey. However, a considerable number of the remainder had liquid within the cavity and swollen walls, indicating that intracellular digestion was taking place (Mackie \& Boag 1963). All the eudoxid bracts contained lipid droplets in the phyllocyst that indicate the existence of energy reserves. A wide variety of prey items were found within the gastrozooids, but Evadne nordmanni $(43 \%)$ was the most common except at Stn 11 There the siphonophores had predominantly been feeding on copepods which were found in $30 \%$ of the gastrozooids. Selection was negative for Oithona similis at Stns 8,16 and 19 but was positive for Temora longicornis and other copepods at Stns 13 and 19. Selection for Evadne nordmanni was positive at Stns 8 and 16. Unidentifiable exoskeletons were found in $18 \%$ of the gastrozoolds. A few harpacticolds, not observed in the medusan guts, were also found. No interspecific predation was observed amongst the 3 hydrozoan species studied.

Finally, a single specimen of the anthomedusan Corymorpha nutans (2 $\mathrm{mm}$ high), collected at Stn 11, was found to have eaten a specimen of Temora longicornis.

\section{Potential predatory impact}

The daily predation rate on copepods was estimated for Aglantha digitale as this species had a relatively high percentage of stomach contents in comparison with the other cnidarians, and because copepods were the most common prey items. Estimates for each station, over a $24 \mathrm{~h}$ period, were calculated for the copepod community and for the 2 most dominant copepod species (Temora longicornis and Oithona similis) using the following formula based on Bajkov (1935):

$$
I=M \cdot\left(C / M_{e}\right) \cdot(1 / D) \cdot 24
$$

where $I$ is the number of copepods ingested per $\mathrm{m}^{3}$ per day, $M$ is the number of medusae per $\mathrm{m}^{3}, C$ is the number of copepods found in the medusae examined, $M_{\mathrm{e}}$ is the number of medusae examined, and $D$ is the digestion time in hours.
We assumed a digestion time of $2 h$, based on the data of Matsakis \& Conover (1991). Since their laboratory experiments were carried out at $4^{\circ} \mathrm{C}$, we believe that our assumption is quite conservative as the water temperature in the fjord was 7 to $7.5^{\circ} \mathrm{C}$. The estimate of ingestion (I) was then divided by the total number of copepods per $\mathrm{m}^{3}$ in order to calculate the percentage of the copepod standing stock eaten per day. The values for each station from the mouth toward the inner fjord in the top $50 \mathrm{~m}$ of the water column were $40.4,145.6$, $42,23.5$ and 96.7 copepods $\mathrm{m}^{-3} \mathrm{~d}^{-1}$. Thus the percentage of the copepod community consumed daily by Aglantha digitale was $0.4,1.5,0.5,0.2$ and $0.3 \%$ respectively. However, if we ignore the nauplii, as none were found in the guts of $A$. digitale, the percentage is $2.5,6.6,2.4,1.8$ and $1.6 \%$ respectively. Fig. 3 shows the average abundance (ind $\mathrm{m}^{-3}$ ) of Temora Longicomis and Oithona similis and the ingestion rate (ind $\mathrm{m}^{-3} \mathrm{~d}^{-1}$ ) of both species by $A$. digitale in the upper $50 \mathrm{~m}$ water column at the different stations in the Hardangerfjord. For $T$ longicornis no correlation

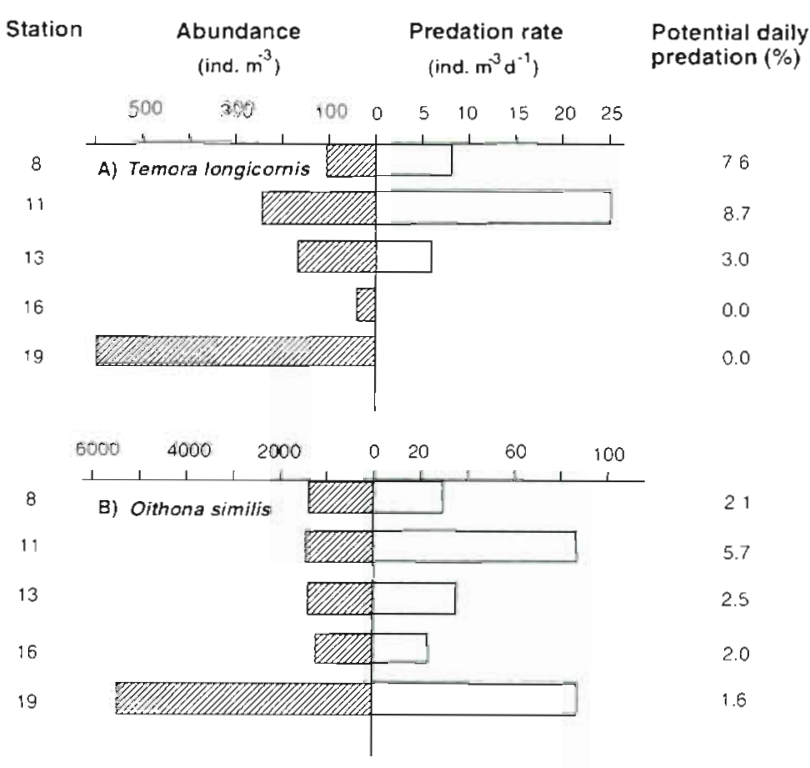

Fig. 3. Percentage of the total abundance (adults plus copepodites) of Temora longicornis and Oithona similis removed daily at each station by Aglantha digitale 
between in situ abundance and ingestion rate was found (Spearman rank correlation, $\mathrm{r}=0.1, \mathrm{p}=0.84, \mathrm{n}=$ 5), while for $O$. similis both parameters were positively correlated $(\mathrm{r}=1.0, \mathrm{p}=0.04, \mathrm{n}=5$ ). The percentage of the total abundance (adults plus copepodites) of these copepods removed daily by $A$. digitale ranged from 0 to $8.7 \%$, and from 1.6 to $5.7 \%$ for $T$. longicornis and O. similis respectively (Fig. 3 ).

\section{DISCUSSION}

All the species collected have been found in other fjords of the northern hemisphere, from the Pacific Ocean (Mackie 1985) to the Barents Sea (Zelickman et al. 1969). Our data clearly show that the vast majority of the planktonic cnidarian population in Hardangerfjord was found in the top $50 \mathrm{~m}$ of the water column. There are various physical and biological factors that could be causing this distribution (Arai 1992), and probably one of the most important ones, according to the results obtained, is the presence of a strong halocline within that depth range, with the salinity increasing from 28.2 to 34.5 psu. However our sampling strategy made it impossible to assess whether the halocline has any effect on the small scale distribution of the various zooplankton species.

In general, medusae from inshore regions are known to be fairly euryhaline. For instance, Lie et al. (1983) found at the nearby Lindaspollene fjord that a small part $(12 \%)$ of the population of Aglantha digitale performed vertical migrations at night in crossing a considerable salinity range (25 to 32 psu). However, Mills (1984) observed that, under laboratory conditions, this trachymedusan species was one of the least tolerant medusae and could not adjust or recover from a transfer from 30.5 to 23.0 psu water However, there were no visible effects when transferred to $27.5 \mathrm{psu}$. This seems to be in accord with the data of Hansen (1951), working in Oslofjord, who found that this species did not migrate above a near-surface discontinuity because, in this case, the surface salinity was much lower (ca 20 psu)

Obelia spp. (meroplanktonic) and Aglantha digitale (holoplanktonic) showed a similar pattern of horizontal distribution. The peak in abundance of both species at Stn 11 suggests that advection of water from the nearby mouth and/or zooplankton aggregations in front of Varaldsoy Island took place, the latter due to eddies formed by the bifurcation of the current. The foreign origin of A. digitale at Stn 11 is based on the bigger size of the bell $(\bar{x}=3.59 \mathrm{~mm}, \mathrm{SD}= \pm 1.81, \mathrm{n}=246)$ when compared with Stn $8(\bar{x}=1.95 \mathrm{~mm}, \mathrm{SD}= \pm 1.08, \mathrm{n}=233)$ and because lipids were the most frequent stomach content $(20.1 \%)$, both features differ notably from the other sta- tions. For instance, in the nearby Masfjord advective processes transport mesozooplankton towards the inner fjord and strongly influence the trophodynamics of the higher trophic levels (Aksnes et al. 1989). Apart from $A$. digitale, Lensia conoidea was the only cnidarian recorded by Lie (1967) in 1955-56, and it is probable that a permanent population inhabits the fjord sustained by a high production of eudoxids.

The positive prey selection of Aglantha digitale for Oikopleura spp. is reported for the first time in this study. Rasmussen (1971) and Smedstad (1972) found that this medusa mostly consumed copepods in Korsfjorden and Oslofjord respectively. This trachymedusan consumed large copepods, copepodites, nauplii and tintinnids in British Columbian waters (Purcell \& Mills 1988, Purcell \& Grover 1990). Selective predation. was suggested in the Canadian fjords where invertebrate eggs were the main prey items (Larson 1987, Matsakis \& Conover 1991) but it does not appear to happen in our study area. The positive correlation between the abundance and ingestion rate of $A$. digitale (Fig. 3) suggests that the abundance of this species is more dependent on prey rather than predators controlling prey numbers. However, there is no further indication that feeding rates per specimen relate to abundance of prey at each station.

The abundance of Aglantha digitale over 1992 in Hardangerfjord is unknown. However, the data about monthly abundance of this species from September 1955 to September 1956 (Lie 1967) show that it occurred only in May-June, with highest densities in May. According to this trend, we could suggest that the potential predatory impact was close to the maximum predation impact since our sampling was made just prior to the potential highest abundance of this species.

The low percentage (15.2\%) of Rathkea octopunctata specimens with food in the stomach is similar to that found for this species (17.5\%) in fjords of the Barents Sea (Zelickman et al. 1969) but is much lower than that observed in Canada ( $75 \%$ ) by Matsakis \& Conover (1991). This medusa was a selective predator (Evadne nordmanni comprised $92 \%$ of the diet) at all stations (Table 4) but its distribution does not appear to follow that of its preferred prey. On the contrary, results from Nova Scotia (Matsakis \& Conover 1991) and the Barents Sea (Zelickman et al. 1969) indicated that its feeding was non-selective. In Nova Scotia, $R$. octopunctata was the most abundant gelatinous carnivore (up to 65 ind $\mathrm{m}^{-3}$ ) from April to June where it preyed mainly on copepods and invertebrate eggs (52.23 and $40.38 \%$ respectively) and itself comprised $34 \%$ of the diet of its potential competitor Aurelia aurita. However, this species consumed barnacle larvae, larvaceans and fish larvae in British Columbian waters (Purcell \& Mills 1988). 
The food of the 4 main cnidarians indicated different feeding preferences. Cladocerans were the main prey item for Rathkea octopunctata and a substantial part of the diet of Lensia conoidea. This is remarkable particularly for $L$. conoidea in spite of the high percentage of unidentified crustacean exoskeletons, because copepods are the main prey of most of calycophoran siphonophores (Purcell 1981).

A series of possible errors might make predation impact estimates unrealistic (Matsakis \& Conover 1991): net feeding, loss of gut contents during and after collection, inaccurate estimates of predator and prey densities, variability in digestion time, diel variations in ingestion rates and differences in the vertical distribution of predators and potential prey. No data about diel variations in ingestion rates for the species studied are known and we believe that only the loss of gut contents could cause underestimation of the predation rate in our study.

In Hardangerfjord, the estimated predatory impact by Aglantha digitale on the total copepod population in the upper $50 \mathrm{~m}$ was low during the short sampling period. Our results match with some previous studies (Daan 1986, 1989, Larson 1987, Purcell et al. 1994) which concluded that a predatory impact rate of gelatinous zooplankton of less than $10 \%$ cannot reduce standing stocks of the crustacean zooplankton. However, the effects of this low impact may vary depending on the developmental state of the copepod community. Egg production experiments were made during the sampling period in the nearby Bjornafjorden. Temora longicornis showed a low egg production rate (between 3 to 25 eggs female ${ }^{-1} \mathrm{~d}^{-1}$ ) that suggested that copepods were food-limited (González et al. 1994). Relatively low chlorophyll concentration (mean $1.15 \mu \mathrm{g}$ $\left.1^{-1}\right)$ and temperature $\left(7.5^{\circ} \mathrm{C}\right)$ and high numbers of large thecate dinoflagellates (e.g. Ceratium spp., Protoperidinium spp.) (Veldhuis et al. 1995), probably too large to be ingested by the small copepod $T$. longicornis, may suggest that the population of this species was growing with a low (or even null) developmental rate On the other hand, Oithona similis showed almost constant weight-specific egg production rates and low fluctuations in biomass all year round, which are in contrast to large seasonal fluctuations experienced by calanoid copepods (Kiørboe \& Nielsen 1994). These authors suggested that this may be related to differences in the functional relationship between fecundity and food availability. In addition, González \& Smetacek (1994) indicated that cyclopoid copepods are able to feed on a wide spectrum of particles, from phytoplankton to zooplankton and detritus (e.g. faecal pellets). Therefore, we should not expect large changes in population dynamics due only to changes in food quality and quantity. Since we did not measure egg pro- duction rate or ingestion rate in $O$. similis, we cannot make any inference about its population developmental rate. Despite the fact that the absolute ingestion rate was higher on $O$. similis than for $T$. longicornis, the predation impact (percentage of the population removed per day) could probably have been higher in the latter than in the former species. Nonetheless, the estimated impact would have been higher if we had been able to estimate the feeding rate of the other cnidarians. The high abundance of Obelia spp. suggests a significant effect on the microplanktonic community.

Many pelagic food-web models of Norwegian fjords include the predation by gelatinous carnivores (e.g. Salvanes et al. 1992) but they do not show any organism consuming them. Apart from the scyphomedusa Cyanea capillata (Bamstedt et al. 1994), the amphipod Hyperia galba is the only predator of gelatinous zooplankton known in Norwegian waters (Dahl 1959). However, we did not observe hyperiid amphipods either associated to the planktonic cnidarians or in the zooplankton samples examined. The quantity and the fate of the energy that passes through this assemblage of the zooplankton is unknown. It would be interesting to deepen the study of the ecology of the carnivorous gelatinous zooplankton inhabiting the fjords in order to incorporate this assemblage into the food-web models

Acknowledgements. We greatly thank P. R. Pugh for his helpful suggestions regarding the manuscript and for improving the language. Slawomir Kwasniewski kindly identified the copepods found in the stomach contents. Information on evacuation rates was kindly provided by A. Jarre-Teichmann. We thank R. Daan for his valuable comments on the manuscript. $M$. Veldhuiss and $M$. Stoll are thanked for providing the chl a and hydrographic data. We are grateful for the professional assistance given by the captain and crew of RV 'Pelagla'. We extend our acknowledgements to 3 anonymous referees for their valuable remarks. Thus study was sponsored by the Spanish Ministry of Education and Science (EX92 46331867) and by The Netherlands Institute of Sea Research through the Emiliania huxleyi project. This is AWI contribution number 873.

\section{LITERATURE CITED}

Aksnes DL, Aure J, Kaardtvedt S, Magnesen T, Richard J (1989) Significance of advection for the carrying capacities of fjord populations. Mar Ecol Prog Ser 50:263-274

Arai MN (1992) Active and passive factors affecting aggregations of hydromedusae: a review. Scientia Mar 56:99-108

Bajkov AD (1935) How to estimate the daily food consumption of fish under natural conditions. Trans Am Fish Soc 65 $288-289$

Baliño BM, Aksnes DL (1993) Winter distribution and migration of the sound scattering layers, zooplankton and micronekton in Masfjorden. Mar Ecol Prog Ser 102:35-50

Båmstedt U, Martinussen MB, Matsakis S (1994) Trophodynamics of the two scyphozoan jellyfishes, Aurelia aurita 
and Cyanea capillata, in western Norway. LCES J mar Sci 51:369-382

Barry B (1974) Hydromedusae of the Canadian eastern Arctic. MSc thesis, McGill University, Montreal

Bouillon J, Boero F, Cicogna F, Gill J.M. Hughes R (1992) Nonsiphonophoran Hydrozoa: what are we talking about? Scientia Mar $56(2-3): 279-284$

Braarud T (1961) The natural history of Hardangerfjord. Sarsia $1: 3-6$

Daan R (1986) Food intake and growth of Sarsia tubulosa (Sars, 1835), with quantitative estimates of predation on copepod populations. Neth J Sea Res 20:67-74

Daan R (1989) Factors controlling the summer development of copepod populations in the Southern Bight of the North Sea. Neth J Sea Res 23:305-322

Dahl E (1959) The hyperiid amphipod. Hyperia galba, a true ecto-parasite on jelly-fish. Univ Bergen Arb, Naturvitensk Rekke 9:1-8

Fossá JH (1992) Mass occurrence of Periphylla periphylla (Scyphozoa, Coronatae) in a Norwegian fjord. Sarsia 77. $237-251$

Fosshagen A (1980) How the zooplankton community may vary within a single fjord system. In: Freeland $\mathrm{HJ}$, Farmer DM, Levings CD (eds) Fjord oceanography. Plenum Publishing Corp. New York, p 399-405

Giske J, Aksnes DL, Baliño BM, Kaartvedt S, Lie U, Nordeide JL, Salvanes AGV, Wakili SM, Aadnesen A (1990) Vertical distribution and trophic interactions of zooplankton and fish in Masfjorden, Norway. Sarsia 75:65-81

González HE, González SR, Brummer GJA (1994) Short term sedimentation pattern of zooplankton, faeces and microplankton at a permanent station in the Bjornafjorden (Norway) during April-May 1992. Mar Ecol Prog Ser 105: $31-45$

González HE, Smetacek V (1994) The possible role of the cyclopoid copepod copepod Oithona in retarding vertical flux of zooplankton faecal material. Mar Ecol Prog Ser 113: $233-246$

Hansen KV (1951) On the diurnal migration of zooplankton in relation to the discontinuty layer. J Cons Perm Int Explor Mer 17:231-241

Kiørboe T, Nielsen TG (1994) Regulation of zooplankton biomass and production in a temperate, coastal ecosystem. I. Copepods. Limnol Oceanogr 39:493-507

Kramp PL (1959) The Hydromedusae of the Atlantic Ocean and adjacent waters. Dana Rep 46:1-283

Larson RJ (1987) Daily ration and predation by medusae and ctenophores in Saanich Inlet, B.C., Canada. Neth J Sea Res 21:35-44

Lie $U$ (1967) The natural history of the Hardangerfjord. 8. Quantity and composition of the zooplankton, September 1955-September 1956. Sarsia 30:49-74

Lie U, Magnesen T, Tunberg B, Aksnes D (1983) Preliminary studies on the vertical distribution of size-fractions in the zooplankton community in Lindåspollene, western Norway. Sarsia 68:65-80

Mackie GO (1985) Midwater macroplankton of British Columbia studied by submersible PISCES IV. J Plankton Res 7:753-777

This article was presented by J. E. Purcell (Senior Editorial Advisor), Cambridge, Maryland, USA
Mackie GO, Boag DA (1963) Fishing, feeding and digestion in siphonophores. Pubbl Staz Zool Napoli 33:178-196

Magnesen T (1988) Horizontal distribution of zooplankton in Lindåspollene, western Norway, May 1979. Sarsia 73 193-204

Matsakıs S, Conover RJ (1991) Abundance and feeding of medusae and their potential impact as predators on other zooplankton in Bedford basin (Nova Scotia, Canada) during spring. Can J Fish Aquat Sci 48:1419-1430

Matthews JBL, Bakke JLW (1977) Ecological studies on the deep-water pelagic community of Korsfjorden (western Norway). The search for a trophic pattern. Helgoländer Wiss Meeresunters 30:47-61

Mills CE (1984) Density is altered in hydromedusae and ctenophores in response to changes in salinity. Brol Bull $166: 206-215$

Pearre S Jr (1982) Estimating prey preference by predators: uses of various indices, and a proposal of another based on $X^{2}$ Can J Fish Aquat Sci 39:914-923

Purcell JE (1981) Dietary composition and diel feeding patterns of epipelagic siphonophores. Mar Biol 65:83-90

Purcell JE, Grover JJ (1990) Predation and food limitation as causes of mortality in larval herring at a spawning ground in British Columbia. Mar Ecol Prog Ser 59:55-61

Purcell JE, Mills CE (1988) The correlation between nematocyst types and diets in pelagic Hydrozoa. In: Hessinger D, Lenhoff $H$ (eds) The biology of nematocysts. Academic Press, San Diego, p 463-485

Purcell JE, White JR, Roman MR (1994) Predation by gelatinous zooplankton and resource limitation as potential controls of Acartia tonsa copepod populations in Chesapeake Bay. Limnol Oceanogr 39:263-278

Rasmussen RE (1971) Om biologien til Aglantha digitale (O. F. Müller) med bemerkninger om forekomsten av de övrige hydromeduser i Korsfjorden, vest Norge. MSc thesis, University of Bergen

Sælen OD (1962) The natural history of the Hardangerfjord. 3. The hydrographical observations 1955-56. Tables of observations and longitudinal sections. Sarsia 6:1-15

Salvanes AGV, Aksnes DL, Giske J (1992) Ecosystem model for evaluating potential cod production in a west Norwegian fjord. Mar Ecol Prog Ser 90:9-22

Smedstad OM (1972) On the biology of Aglantha digitale rosea (Forbes) [Coelenterata: Trachymedusae] in the inner Oslofjord. Norw J Zool 20:111-135

Veldhuis JM, Stoll M, Bakker D, Brummer GJ, Kraak M, Kop A, van Weerlee E, van Koutrik A, Heimdahl BR (1995) Calcifying phytoplankton in Bjornafjorden. Norway. The prebloom situation. Sarsia 79:389-399

Williams R, Conway DVP (1981) Vertical distribution and seasonal abundance of Aglantha digitale (O. F. Müller) (Coelenterata: Trachymedusae) and other planktonic coelenterates in the northern Atlantic Ocean. J Plankton Res 3: $633-643$

Zar JH (1984) Biostatistıcal analysis. Prentice-Hall, Inc. Englewood Cliffs, NJ

Zelickman EA, Gelfand VI, Shifrin MA (1969) Growth, reproduction and nutrition of some Barents Sea hydromedusae in natural aggregations. Mar Biol 4:167-173

Manuscript first recelved: January 5, 1995

Revised version accepted: April 25, 1996 